\title{
Teaching the Life Sciences
}

\section{M. J. Kramer}

TD, MA (Cantab), PhD (Lond), F Inst Biol;

formerly Senior Biology Master, City of London School;

Senior Biology Master, Eton College; Lecturer in the Education Department, Exeter University

Macmillan 
ISBN 978-1-349-02130-7 ISBN 978-1-349-02128-4 (eBook)

DOI 10.1007/978-1-349-02128-4

(C) L. M. J. Kramer 1975

Softcover reprint of the hardcover 1st edition 1975 978-0-333-15580-6

All rights reserved. No part of this publication may be reproduced or transmitted in any form or by any means without permission

First published 1975

Published by MACMILLAN EDUCATION LTD

London and Basingstoke

Associated companies and representatives

throughout the world 
I dedicate this book to my wife ROSEMARY PEGGY

in gratitude for her continual

support and encouragement and for creating conditions which made the work possible 


\section{Contents}

Acknowledgements vii

Introduction ix

1 Dedication and initiation 1

2 The teacher as biological scientist 11

3 In contact with children 34

4. The essential techniques 57

5 The lesson as a work of art 102

6 Constructing teaching schemes 122

7 Adapting to the pupil's needs 152

8 Assessment and examinations 176

9 You and your school 198

Index 209 


\section{Acknowledgements}

During a professional career one is inevitably indebted to many people; I am sure that I have absorbed ideas from colleagues and pupils. It is impossible to thank so many unwitting helpers individually, but specific thanks are owed to those now named for help with this book.

Mr R Jones, Head, and other members of the Science Department, and Mr D. Leach, Head of the Visual Education Department, at Rolle College, Exmouth, for various assistance; my former pupils Miss J. Breukelman and Miss G. Stock for comments: and my own University of Exeter for library facilities.

The following helped with photography in several ways: Mr C. G. Carré, Lecturer, and Mr R. Davey, Senior Technician of Exeter University Education Department; Mr A. Worthington, Head, and other members of the Science Department at Queen Elizabeth School, Crediton; Mr A. Dunstan of Exeter; Fiona and Andrew Hyland and Vivienne Raddan.

L. M. J. Kramer 


\section{Note on References}

The relevant literature is listed at the end of each chapter, and referred to in the text by numbers. .

Certain works cover a wide range of subjects and may be called General References. These are designated in the text by an asterisked number. Full details of these works are listed under their appropriate number at the end of the book.

The School Science Review is referred to as $S S R$ and the Journal of Biological Education as J. Biol. Ed. throughout.

At the end of chapter 6, there is, in addition to the usual list, a further list of numbered papers on specific branches of biology. These are referred to in the text by superior numerals, e.g. Taylor ${ }^{166}$. 


\section{Introduction}

The drama of the modern insight into the nature of the living world has not only brought biology to the front of scientific advance but has also aroused fresh public interest. Terms like ecology, conservation and pollution are constantly used, and not always accurately. At the same time, social currents are reacting with each other in response to population pressures, immigration, and the economic background.

The meeting of social change, science and school life has produced an exciting challenge for the aspiring or practising teacher. Although the large urban comprehensive schools have intriguing problems, there are as many in other types of schools, and within wide limits there are three chief needs to be met in the study of biology. Every child requires a broad health education, and an appreciation, within the limits of his understanding, of biological factors; and each child must learn how these work in his particular surroundings. These two needs most often have to be met in mixed ability groupings. Thirdly, from among such groups we have to meet the nation's call for future science specialists in biologically-related industries and callings, without whom the technological and scientific agricultural activities would not survive. Part of the strain of current conditions results from the fact that only a small proportion of pupils will really grasp the nature of biological science, whereas a course must also meet the partly non-scientific needs of the majority. This complex situation presents opportunities for mistakes as well as for valuable influences and adventurous teaching.

The teaching of biology raises additional problems. Its expansion in the past decade reflects its greater influence, and is also coupled with the difficulties and advantages of rearing and slaughtering thousands of specimens in what are really small zoos and botanical gardens. 
Few biology books take account of the now great volume of relevant British educational research, and it is remarkable how teachers of all ages stress the dominating value of the teaching practice during training. My experience of educating aspiring teachers and of responsibility for those in their first posts has revealed how necessary it is to understand the universally applicable, well-tried principles of teaching.

The present book, which has grown from these considerations, has certain clear aims and boundaries.

1 It deals with teaching systems and so is not a book from which to learn biology.

2 It is not a laboratory manual giving specific procedures which are learned in science courses or looked up in the range of books found in colleges and schools.

3 It does deal with the secondary school age range.

4. It comprises a reasoned and logical survey of every aspect of biology teaching and aims to be far deeper than any made recently, in order to provide students with the step-by-step guidance they seek in order to teach the increasingly incisive subject of biology today. Because the survey is worked out from first principles of science and of the nature of children, it is independent of fashion and so cannot date or fail to be applicable to every type of secondary school. It goes behind and beyond every approach by displaying the basis of every means of contact with children. The excitement of teaching modern biology can only be made manifest if professional and scientific training are its precursors, and it is a soundly conceived amalgam of the teacher's temperament, appropriate content and an imaginative use of the locality of the school. Another aim of the book therefore is to complement systems like the Nuffield Science Teacher Education Project and to instruct students how to become self-reliant and to create their personal teaching schemes. This is vital for isolated teachers or those who are the only specialists in their schools.

5 Until now there has been no comprehensive and systematic grouping of references for school biology in Great Britain. The book therefore contains 450 classified references to the works found in every training establishment and good school, chiefly the past twenty years of the School Science Review and the 
Journal of Biological Education. They have been collated with regard to each phase of the reasoned survey so that the text is a synopsis of the modern outlook. Because they are classified they provide students, teachers and tutors in colleges and universities with a reference list for projects, writing theses and working up branches of the subject and its teaching.

6 Laboratory design is omitted because it does not often concern a beginner and may never concern a teacher, who usually has to do the best he can in existing premises.

Despite the striking advances in education during the past half-century biological ignorance and its consequences are greater than they should be, so that teachers have now the opportunity to achieve more than has previously been possible. Social need and the possibilities of scientific discoveries are powerful incentives to embark on the crusade for the force the subject has become. 